PhD in Pedagogical Sciences, Associate Professor, ANTONINA CHYCHUK

Bohdan Khmelnytskyi Cherkasy National University Address: 81 Shevchenko Blvd., Cherkasy, 18031, Ukraine E-mail: tetyanna@ukr.net

\title{
PROVIDING RETRAINING AND ADVANCEMENT TRAINING FOR PRIMARY/ELEMENTARY SCHOOL TEACHERS AT THE STATE LEVEL IN GREAT BRITAIN AND THE USA
}

\begin{abstract}
In Great Britain and the USA the normative basis of primary/elementary school teachers' qualification advancement is being actively developed, i. e. this issue is considered at the state level. For a long time the development of retraining and advancement training system for primary/elementary school teachers has been grounded on conceptual foundations of pedagogy that ensures the functionality of the mentioned system. The research results on conceptual foundations for forming an education system of teacher qualification advancement in Great Britain and the USA prove that their nature depends on the development of these countries' history. In particular, there is a trend towards integrating course- and school-based forms of qualification advancement on the ground of teachers' collaboration with lectures; raising the question of making the education process of primary/elementary school teachers' qualification advancement more democratic; creating a participatory style of learning that is carried out collectively (teachers actively develop the programme content and propose to include such issues that are necessary for their solving during these courses).

Key words: retraining, qualification advancement, primary/elementary school teachers, Great Britain, the USA.

\section{INTRODUCTION}

Retraining and advanced training of primary school teachers became of great interest in the mid 1960s in Great Britain. Teaching departments at universities were the basis of teacher retraining and advancement training system (Department of Education and Science, 1978). Today, advanced training of primary school teachers and their retraining is carried out at the national level.

In Great Britain during the 1950-70s they developed a normative basis: for the government to participate in the system of primary school teachers qualification advancement ("The Employment and Training Act (1973), "The Education (Work Experience Act" (1973), counseling services, the National Committee for In-Service Training of Teachers within the National Council for Curriculum and Assessment, INSET providing agencies to ensure the functionality of those courses designed for primary school teachers' qualification advancement.

In the 1980 they adoped the Education Act according to which the government was to develop general national recommendations reflected on the practical actions due to the use of market financing mechanisms in order to unify the programs of teacher advancement programs (Гаргай, 2006).
\end{abstract}


In 1983 in Great Britain they introduced the grant-based system. The Comittee on Workforce Resources at the Department for Employment and Learning was appointed responsible for their funding, however, they were allowed to fund only those qualification advancement programs that corresponded to the national priorities. This School Improvement Grant Technology forces universities to compete for the right to receive funds for the development of qualification advancement programs for primary school teachers (Гаргай, 2006; Department of Education and Science, 1986).

P. Drucker indicates that in the initiative "For Better School" they raise the question of the dependence of education systems on the market laws, school efficiency, quality education provision at schools (Drucker, 1994).

In his report "Changing the World of Education" (1995) T. Corcoran raised the question of the qualification advancement of those specialists who work with teachers: develping new standards; motivating teachers toward self-ditected learning; implementing pedagogical information technologies at schools.

In the USA they have taken appropriate measures in legislature that should have enhanced the applicants' interest in studying in pedagogical higher education institutions. In particular, the University Honor Program, Future Teachers Corps Program provided for the scholarship fund establishment to foster the training of future teachers that are willing to work in critical fields. In the context of the Higher Education Act there were created the programs of Perkins Loans and Paul Douglas Teacher Scholarship Program that provide those graduates that are ready to work in rural areas and in 1989 they allotted 22 million dollars. Also, they adopted the Comprehensive Employment and Training Act and thus established the fund for education quality enhancement where $0,5 \%$ of the amount of each contact that demands the permission of the federal government is transferred to their account. The Department of Education must transfer some earnings to education agencies to provide teachers from national minorities with relevant training.

"America 2000: An Education Strategy" also played a significant role in the development of higher pedagogical education as it considered education as the main object of the reform and fostered innovative ideas (Андрєєва, 2000).

So, in Great Britain and the USA the normative basis of primary/elementary school teachers' qualification advancement is being actively developed, i. e. this issue is considered at the state level.

THE AIM OF THE STUDY

The aim of the study is to reveal the peculiarities of providing retraining and qualification advancement of primary/elementary school teachers at the state level in Great Britain and the USA.

\section{THEORETICAL FRAMEWORK AND RESEARCH METHODS}

The problem of primary/elementary school teachers' advancement training in Great Britain and the USA has been actively studied by both native and foreign scholars (H. Andrieieva, C. A. Anderson, Ya. Bondaruk, A. Carol, G. A Cowan, P. Drucker, J. Floud, A. H. Halsey, V. Harhai, W. D. Hawley, S. Mehaffie, C. Reavis, D. F. Reed, J. T. Seyfarth, K. Zyskin). However, we believe it necessary to study the outlined problem from our own point of view and present relevant insights that may be successfully used by other scholars within their researches.

To achieve the set aim such methods as analysis, synthesis, generalization and systematization have been used. 


\section{RESULTS}

It should be mentioned that for a long time the development of retraining and advancement training system for primary/elementary school teachers has been grounded on conceptual foundations of pedagogy that ensures the functionality of the mentioned system.

In Great Britain the state policy is directed at centralization that contributed to the establishment of the concept of creative paertnership, according to which the regulation was viewed mainly in the context of power integration between subjects. The government recognizes the policy of egalitarian education (the equality of educational opportunities) that the experts opposed to (Гаргай, 2006).

The concept of investing in education as a key to economic and social progress as the theory of human capital is an ideological basis of the statement that economic development depends on the erudition of people in the country (Halsey, Floud, Anderson, 1961).

In the 1980-90s of the 20th century, the government authorized educators to enhance the quality of teacher education, including primary/elementary teacher education. In the 1980 s, they established a general theoretical conception of enhancing quality of primary school teachers' advancement training that later on played a significant role in solving this issue. As it is indicated in the periodicals of the 1980s (British Journal of In-Service Education), while developing theoretical foundations of teachers' qualification advancement, there occurred the integration of training and professional activity of primary school teachers that depends on the knowledge that fosters the efficiency of teachers' personal and professional development (Carol, 1988; Cowan, 1984).

The general theoretical conception of enhancing the quality of teachers' qualification advancement reflects the trend towards integrating training and professional activity of primary/elementary school teachers as well as takes into account meeting the needs of schools. Based on the mentioned integration, one can observe a forming of new relations between course- and school-based training that results in the trend towards these forms' infusion based on the collaboration of teachers and lectures (Гаргай, 2006).

Foreign scholars W. D.Hawley, S. Rosen-holtz et al. also raised the quiestion of making the education process of primary/elementary school teachers' qualification advancement more democratic. To enhance the quality of learning, it is necessary to implement a participatory style of learning that is carried out collectively. Primary/elementary school teachers together with the leaders of the qualification advancement courses outline the tasks of the program, develop the training content (in order to include those issues they are interested in) as well as solve the outlined tasks to at most integrate the obtained methodology technologies in the school environment according to V. Harhai's findings. In order to comprehend their mission, primary/elementary school teachers should be able to theoretically justify their recommended technologies and methods of learning that will enable them to combine theoretical knowledge with difficulties that may appear during professional activity (Гаргай, 2006; Hawley, Rosenholtz, 1984).

In our opinion, the participatory approach to the organization of primary/elementary school teachers' qualification advancement, that is when primary/elementary school teachers take part in in the development of programs and propose to include such issues that are necessary for their solving during these courses, is extremely essential in their professional activity. Moreover, rather important is their active participation in their 
solving, since only then the implementation of the obtained knowledge, solved issues in the education process will be carried out clearly and deliberately.

After their completing the qualification advancement courses, they should be assessed and provided with the information on positive changes in their work. Thus, they collect the reviews of elementary school teachers, administrators, organize questionnaires; testing of pupils allows to define those changes that occurred in their development. Taking into account the disadvantages in conducting the courses, the authors help teachers to draw an individual plan of after-course professional development. V. Harhai indicates that in such a way they are motivated toward further self-directed learning with the help of group tutors (they provide counseling on organization and conduct of researches) (Гаргай, 2006).

According to the connectionism theory, American scholars such as S. Mehaffie, C. Reavis, D. Reed and J. Seyfarth have identified a range of important skills that qualified teachers, including rural teachers, should have. Thus, they need to know how to organize an interaction with their pupils on a friendly basis; conduct lessons in classes of different levels; to maintain approapriate classroom discipline; to strive for self-development (Reavis, Mehaffie, 1984; Reed, Seyfarth, 1984; Андрєєва, 2000).

The data of the American Association for Employment in Education prove that school districts in the USA hire teachers without traditional teacher education due to a lack of teachers (Math and Biology teachers - 36\%, Physics and Chemistry teachers $-20 \%$, teachers for children with special educational needs $-16 \%$, Spanish teachers $-15 \%$ ) that has resulted in the appearance of alternative programs for teacher certification. In particular, in 2010 forty-eight states and the District of Columbia already had 600 alternative programs (Бондарук, 2013; American Association for Employment in Education, 2010).

\section{CONCLUSIONS}

The research results on conceptual foundations for forming an education system of teacher qualification advancement in Great Britain and the USA prove that their nature depends on the development of these countries' history. In particular, there is a trend towards integrating course- and school-based forms of qualification advancement on the ground of teachers' collaboration with lectures; raising the queston of making the learning process of primary/elementary school teachers' qualification advancement more democratic; creating a participative style of learning that is carried out collectively (teachers actively develop the programme content and propose to include such issues that are necessary for their solving during these courses).

As for further researches we consider perspective to develop a methodical complex consisting of special courses and textbooks for students and hearers of qualification advancement courses for teachers and implement it in the education process as it will improve teacher training in Ukraine.

\section{REFERENCES}

1. American Association for Employment in Education. (2010). Education Supply and Demand in the United States. Columbus, OH : American Association for Employment in Education, Inc., 12 p.

2. Carol, A. (1988). Guidelines for an Effective Evaluation. British Journal of In-Service Education, Volume14, Issue 3, pp. 140-146. 
3. Cowan, G. A (1984). Schedule of Teaching Skills: an Aid to Self-Evaluation, Development and Assessment. British Journal of In-Service Education, Volume 11, Issue 1, pp. 36-38.

4. Department of Education and Science. (1986). Local Education Training Grants Scheme; Financial Year 1978-1988 Circular No 6/86. London : DES, 112 p.

5. Department of Education and Science. (1978). Statistical Review. London : HMSO, $45 \mathrm{p}$.

6. Drucker, P. (1994). Post-Capitalist Society. Oxford : ButterworthHeinemann, $232 \mathrm{p}$.

7. Halsey, A. H., Floud, J., Anderson, C.A. (1961). Education, Economy and Society. New York : Free Press of Glencoe, 625 p.

8. Hawley, W. D., Rosenholtz, S. (1984). Good Schools: A Synthesis of Research on How Schools Influence Student Achievement. Peabody Journal of Education, Volume 4, pp. 1-178.

9. Reavis, C., Mehaffie, S. (1984). Staff Recruitment and In-service Development in Smaller Schools. NASSP Bulletin, No 64 (438), pp. 32-33.

10. Reed, D. F., Seyfarth, J. T. (1984). Assessing Needs in Rural Schools. The Rural Educator, Volume 1, No 6, pp. 12-18.

11. Андрєєва, Г. Б. (2000). Подготовка, адаптация и повыщение квалификации сельских учителей [Training, Adaptation and Qualification Advancement of Rural Teachers]. Thesis for PhD. M., 154 p. (in Russian).

12. Бондарук, Я. В. (2013). Організачія навчального процесу в системі підвищення кваліфікації вчителів у США [The Organization of Education Process in the System of Teachers' Qualification Advancement in the USA]. Thesis for PhD. Черкаси, 209 p. (in Ukrainian).

13. Гаргай, В. Б. (2006). Развитие системы повымения квалификации учителей в Великобритании (конеи XIX-конеи XX вв.) [The Development of Teachers' Qualification Advancement System in Great Britain (the late 19th-20th Centuries]. Thesis for a Doctoral Degree. Новосибирск, 379 p. (in Russian).

14. Зискин, К. Е. (2002). Профессионально-педагогическая подготовка учителей средней школь на педагогических отделениях университетов Великобритании во второй половине ХХ в. [Professional Pedagogical Training of Middle School Teachers within Pedagogical Departments at British Universities in the Second Part of the 20th Century]. Thesis for PhD. Москва, 157 p. (in Russian). 